\title{
Impact of nitrogen addition on plant community in a semi-arid temperate steppe in China
}

\author{
Ling SONG ${ }^{1}$, XueMei BAO ${ }^{1}$, XueJun LIU $^{1,2^{*}}$, FuSuo ZHANG $^{1}$ \\ ${ }^{1}$ Key Laboratory of Plant-Soil Interactions, Ministry of Education, College of Resources and Environmental Sciences, China \\ Agricultural University, Beijing 100193, China; \\ ${ }^{2}$ Xinjiang Institute of Ecology and Geography, Chinese Academy of Sciences, Urumqi 830011, China
}

\begin{abstract}
Increased nitrogen $(\mathrm{N})$ deposition will often lead to a decline in species richness in grassland ecosystems but the shifts in functional groups and plant traits are still poorly understood in China. A field experiment was conducted at Duolun, Inner Mongolia, China, to investigate the effects of $\mathrm{N}$ addition on a temperate steppe ecosystem. Six $\mathrm{N}$ levels $\left(0,3,6,12,24\right.$, and $\left.48 \mathrm{~g} \mathrm{~N} /\left(\mathrm{m}^{2} \cdot \mathrm{a}\right)\right)$ were added as three applications per year from 2005 to 2010. Enhanced $\mathrm{N}$ deposition, even as little as $3 \mathrm{~g} \mathrm{~N} /\left(\mathrm{m}^{2} \cdot \mathrm{a}\right)$ above ambient $\mathrm{N}$ deposition $\left(1.2 \mathrm{~g} \mathrm{~N} /\left(\mathrm{m}^{2} \cdot \mathrm{a}\right)\right)$, led to a decline in species richness of the whole community. Increasing $N$ addition can significantly stimulate aboveground biomass of perennial bunchgrasses (PB) but decrease perennial forbs (PF), and induce a slight change in the biomass of shrubs and semi-shrubs (SS). The biomass of annuals (AS) and perennial rhizome grasses (PR) accounts for only a small part of the total biomass. Species richness of PF decreased significantly with increasing $N$ addition rate but there was a little change in the other functional groups. $\mathrm{PB}$, as the dominant functional group, has a relatively higher height than others. Differences in the response of each functional group to $\mathrm{N}$ addition have site-specific and species-specific characteristics. We initially infer that $\mathrm{N}$ enrichment stimulated the growth of $\mathrm{PB}$, which further suppressed the growth of other functional groups.
\end{abstract}

Keywords: nitrogen addition; species richness; biomass; functional group; temperate steppe; Duolun, Inner Mongolia

Plant species diversity plays an important role in maintaining ecosystem sustainability and function. But it was recognized to be threatened by atmospheric nitrogen $(\mathrm{N})$ deposition at the global scale (Bobbink et al., 2010). Due to the implement of stricter legislation to limit atmospheric pollution, the rates of $\mathrm{N}$ deposition in the USA and Europe have been leveled off or stabilized since the late 1980s or early 1990s (NADP, 2000). In China, both reactive $\mathrm{N}$ emission and deposition caused mainly by growing agricultural and industrial activities have been increasing continuously since the 1980s (He et al., 2010; Liu et al., 2011). This enhanced $\mathrm{N}$ deposition, as a $\mathrm{N}$ nutrient resource, can stimulate biomass increase, while decreases species richness, affects community composition, and influences ecosystem functions. And its impacts vary considerably among ecosystems (Matson et al., 2002; Niu et al., 2010; Meng et al., 2011).
Grassland ecosystems, where nutrient inputs have historically been very low, are very sensitive to $\mathrm{N}$ enrichment condition. Even a 23 years adding of another $1 \mathrm{~g} \mathrm{~N} /\left(\mathrm{m}^{2} \cdot \mathrm{a}\right)$ of $\mathrm{N}$ fertilizer will reduce plant species numbers by $17 \%$ relative to controls receiving ambient $\mathrm{N}$ deposition of $0.6 \mathrm{~g} \mathrm{~N} /\left(\mathrm{m}^{2} \cdot \mathrm{a}\right)$ in the USA, and loss of species mainly occurred in rare species which has lower initial abundance (Clark and Tilman, 2008). Effects of increased $\mathrm{N}$ availability on community composition had also been well studied experimentally in European species-rich grassland (Bobbink et al., 2003). Bobbink et al. (2004) conducted a series of $\mathrm{N}$ addition field experiments in temperate semi-natural grasslands in Europe, including both wet and dry grasslands, and they found a significant negative relationship between

Received 2011-08-05; accepted 2011-10-28

*Corresponding author: XueJun LIU (E-mail: liu310@cau.edu.cn) 
species richness and $\mathrm{N}$ addition rates within the range of 0 to $4 \mathrm{~g} \mathrm{~N} /\left(\mathrm{m}^{2} \cdot \mathrm{a}\right)$. Other studies also found that species richness may be reduced in areas with ambient $\mathrm{N}$ loads exceeding $2 \mathrm{~g} \mathrm{~N} /\left(\mathrm{m}^{2} \cdot \mathrm{a}\right)$ due to a long-term cumulative $\mathrm{N}$ deposition for decades (Jones and Kielland, 2002; Emmett et al., 2007). For example, Stevens et al. (2004) found that grass species richness in acidic soils decreased linearly with increasing $\mathrm{N}$ deposition (ranging from 0.5 to $3.5 \mathrm{~g} \mathrm{~N} /\left(\mathrm{m}^{2} \cdot \mathrm{a}\right)$ ) in Britain.

Species response to increased $\mathrm{N}$ availability depends on factors such as successional stage, ecosystem type, $\mathrm{N}$ demand or retention capacity, land-use history, soil, topography, climate, and the rate, timing, and type of $\mathrm{N}$ fertilizer (Matson et al., 2002). As a main grassland of China and part of the Eurasian steppe, the Inner Mongolia steppe plays an important role in species diversity maintenance and conservation. But inadequate attention has been paid to study how this temperate steppe responds to increased $\mathrm{N}$ deposition. Bai et al. (2010) recently demonstrated the tradeoffs and thresholds in the effects of $\mathrm{N}$ addition on grassland biodiversity and ecosystem functioning. Their results suggested that the critical threshold of $\mathrm{N}$-induced species loss for mature Eurasian grassland may be below $1.75 \mathrm{~g} \mathrm{~N} /\left(\mathrm{m}^{2} \cdot \mathrm{a}\right)$, and changes in aboveground biomass, species richness, and plant functional group composition for both mature and degraded ecosystems saturated at approximately $10.5 \mathrm{~g} \mathrm{~N} /\left(\mathrm{m}^{2} \cdot \mathrm{a}\right)$. Changes in community abundance and biomass were also found to be associated with soil mineral $\mathrm{N}$ content (Song et al., 2011). In order to get a general cognition about how the various functional groups respond to increased $\mathrm{N}$ deposition in China, we need more studies in this vulnerable region.

\section{Materials and methods}

\subsection{Study area}

The Duolun Grassland Research Station of Chinese Academy of Sciences is located in Duolun county $\left(42^{\circ} 02^{\prime} \mathrm{N}, 116^{\circ} 17^{\prime} \mathrm{E} ; 1,324 \mathrm{~m}\right.$ asl), a semi-arid area in Inner Mongolia with a mean annual temperature of $2.1^{\circ} \mathrm{C}$. The maximum and minimum mean monthly temperatures were $18.9^{\circ} \mathrm{C}$ in July and $-17.5^{\circ} \mathrm{C}$ in January, respectively. The area is characterized by a continental monsoon climate. The mean annual precipitation is $313 \mathrm{~mm}$, with $94 \%$ distributed from May to October, and the mean potential evaporation is $1,748 \mathrm{~mm}$. The soil is classified as a chestnut soil (Chinese classification) or Calcic Luvisols according to the FAO classification, with sand, silt and clay contents of $(62.8 \pm 0.04) \%,(20.3 \pm 0.01) \%$, and $(16.9 \pm$ $0.01) \%$, respectively. Mean soil bulk density and soil $\mathrm{pH}$ are $1.31 \mathrm{~g} / \mathrm{cm}^{3}$ and 7.12 , respectively. Soil $(0-10$ $\mathrm{cm}$ depth) organic $\mathrm{C}$, total $\mathrm{N}$, and total $\mathrm{P}$ are 12.3, 1.7 and $0.28 \mathrm{~g} / \mathrm{kg}$, respectively. According to Zhang et al. (2008) and Shen et al. (2009), ambient annual N wet and dry deposition in this area is about $16 \mathrm{~kg} \mathrm{~N} / \mathrm{hm}^{2}$ in total. The study site has been fenced off since 2001 to protect it from grazing disturbance. The experimental field belongs to a typical steppe community and the dominant plant species in this temperate grassland are Artemisia frigida Willd, Stipa krylovii Roshev., Potentilla acaulis L., Cleistogenes squarrosa (Trin.) Keng, Allium bidentatum Fisch. ex Prokh. and Agropyron cristatum (L.) Gaertn.

\subsection{Experimental design}

We used a randomized block design with five (in 2005) or six (after 2006) treatments and five replicate plots for each treatment. Thirty $5 \mathrm{~m} \times 5 \mathrm{~m}$ plots were arranged in a $5 \times 6$ matrix. The distance between any two adjacent plots was $1 \mathrm{~m}$. $\mathrm{N}$ fertilizer was added at the rates of $0,3,6,12,24$, and $48 \mathrm{~g} \mathrm{~N} /\left(\mathrm{m}^{2} \cdot \mathrm{a}\right)$ as $\mathrm{NH}_{4} \mathrm{NO}_{3}$ except in the first year (urea was applied in 2005). The $3 \mathrm{~g} \mathrm{~N} /\left(\mathrm{m}^{2} \cdot \mathrm{a}\right)$ treatment started in 2006 and the $48 \mathrm{~g} \mathrm{~N} /\left(\mathrm{m}^{2} \cdot \mathrm{a}\right)$ treatment was not applied in 2009 and 2010. The fertilizer for each plot was split into 3 equal dressings applied in early June, July and August. The experiment started in 2005 and continued to 2010 , but no data were collected in 2007 .

\subsection{Vegetation sampling and analysis}

We divided all the plants into five functional groups according to species life form: perennial bunchgrasses $(\mathrm{PB})$, perennial rhizome grasses (PR), perennial forbs (PF), shrubs and semi-shrubs (SS), and annuals (AS). All vegetation sampling (except for biomass) was done non-destructively because the experiment was designed to investigate the long-term responses of plant community to cumulative N addition. Sampling was conducted at the end of August 2005, 2006, 2008, 2009 and 2010 when the sward had the highest biomass during the year (Chen et al., 2011). Visual estimates involved vegetation cover and species richness 
to test the changes in grassland community in response to $\mathrm{N}$ addition. One permanent quadrat $(1 \mathrm{~m} \times 1 \mathrm{~m})$ was established at each subplot in May 2005. During measurement, a frame $(1 \mathrm{~m} \times 1 \mathrm{~m})$ with 100 equally distributed grids at $10-\mathrm{cm}$ interval was placed above he canopy in each quadrat. The percentage of each species cover was estimated visually in all grid cells, the sum of which in each quadrat was accordingly considered to be the coverage of each species. Canopy height of each species within a plot was the mean values of at least five random measurements of the species height. Species richness was defined as the number of different species in each quadrat. In addition, we also used the Shannon-Wiener index $(H)$ and Pielou index evenness $(E)$ to describe the patterns of plant community structure. $H$ was calculated as:

$$
H=-\sum P_{i} \ln P_{i},
$$

E was calculated as:

$$
E=\left(-\sum P_{i} \ln P_{i}\right) / \ln S .
$$

Where $P_{i}$ is the relative coverage of species $i$ and $S$ is species richness.

Aboveground vegetation was sampled each year between 25 and 30 August by clipping all plant species at the soil surface. A quadrat $(1 \mathrm{~m} \times 1 \mathrm{~m})$ was placed within each plot at random to avoid overlap with the permanent quadrat used for vegetation sampling and at least $50 \mathrm{~cm}$ away from the edge of the plot to avoid edge effects. All living vascular plants were sorted by species, and green vegetation, which were separated from litter and standing dead samples, was oven dried for $48 \mathrm{~h}$ at $65^{\circ} \mathrm{C}$ and weighed for aboveground biomass.

\subsection{Statistical analysis}

Statistical difference in the mean values of the indicators of all treatments was compared by least significant difference (LSD) at a 5\% level using the SAS V. 8.1 software (SAS Institute Inc., Cary, NV, USA).

\section{Results}

\subsection{Species richness, species diversity and even- ness in community}

Mean Shannon-Wiener index $(H)$, Pielou index evenness $(E)$ and average species richness in the sampled quadrat $(1 \mathrm{~m} \times 1 \mathrm{~m})$ within the plots across all treatments and years were 1.40, 0.57 and 12.22 , respectively (Fig. 1). Species richness declined linearly with
$\mathrm{N}$ addition rate and year. In the first year (2005), there were no changes in species richness between treatments. A significant decline in species richness occurred in the $48 \mathrm{~g} \mathrm{~N} /\left(\mathrm{m}^{2} \cdot \mathrm{a}\right)$ treatment in 2006. From 2008 to 2010 , even the $12 \mathrm{~g} \mathrm{~N} /\left(\mathrm{m}^{2} \cdot \mathrm{a}\right)$ treatment significantly decreased in species richness. When comparing the same treatment among years, we found that species richness declined with year across all treatments (Fig. 1). Both $H$ and $E$ declined with increasing $\mathrm{N}$ addition rate except for the first year when no responses occurred for most species. The $H$ values varied with year and did not show a consistent trend. The highest (2.09) and lowest (0.74) $H$ values occurred in 2008. The $E$ values, which varied from 0.37 to 0.77 , increased with year. When the $\mathrm{N}$ addition rate was lower than $6 \mathrm{~g} \mathrm{~N} /\left(\mathrm{m}^{2} \cdot \mathrm{a}\right)$, the $E$ values did not show significant differences among years from 2008 to 2010 (Fig. 1).

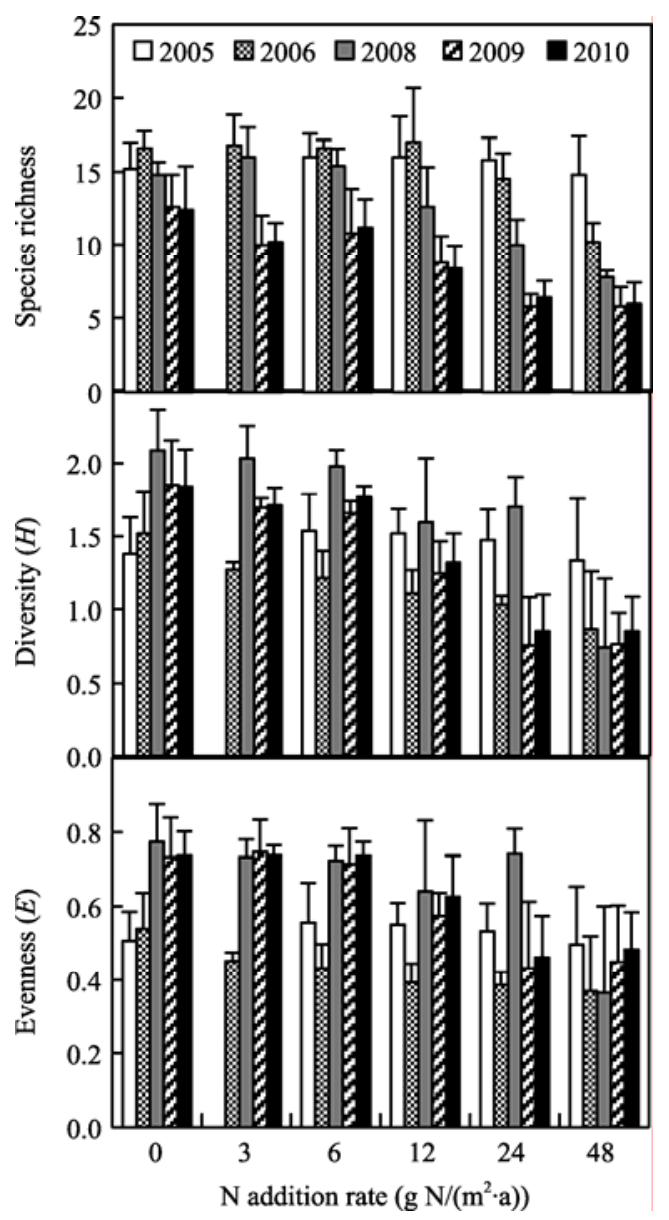

Fig. 1 Effects of increased $\mathrm{N}$ addition on species richness of community (SP), Shannon-Wiener index $(H)$ and Pielou index evenness $(E)$ within the quadrats $(1 \mathrm{~m} \times 1 \mathrm{~m})$ from 2005 to 2010 . 
Table 1 Major species of different functional groups within the quadrats ( $1 \mathrm{~m} \times 1 \mathrm{~m}$ ) from 2005 to 2010

\begin{tabular}{|c|c|c|}
\hline Functional groups & Species & $\begin{array}{c}\text { Relative coverage } \\
(\%)\end{array}$ \\
\hline \multirow[t]{6}{*}{$\begin{array}{l}\text { Perennial } \\
\text { bunchgrasses (PB) }\end{array}$} & Achnatherum sibiricum & \\
\hline & Agropyron cristatum & 10.9 \\
\hline & Cleistogenes squarrosa & 2.44 \\
\hline & Koeleria cristata & \\
\hline & Poa sphondylodes & 1.36 \\
\hline & Stipa krylovii & 35.99 \\
\hline \multirow{10}{*}{$\begin{array}{l}\text { Perennial rhizoma- } \\
\text { tous grasses (PR) } \\
\text { Annual and biennial } \\
\text { (AB) }\end{array}$} & Leymus chinensis & 0.31 \\
\hline & Setaria viridis Beauv & \\
\hline & Androsace umbellata & \\
\hline & Chamaerhodos erecta & \\
\hline & Chenopodium aristatum & \\
\hline & Chenopodium glaucum & \\
\hline & Dontostemon dentatus & \\
\hline & Gentiana squarrosa & \\
\hline & Salsola collina & \\
\hline & Silene conoidea & \\
\hline \multirow[t]{28}{*}{ Perennial forb (PF) } & Allium bidentatum & \\
\hline & Allium neriniflorum & 2.71 \\
\hline & Allium ramosum & \\
\hline & Allium senescens & \\
\hline & Allium tenuissimum & \\
\hline & Artemisia capillaris & \\
\hline & Astragalus galacties & 1.46 \\
\hline & Astragalus scaberrimus & 1.23 \\
\hline & Carex korshinskyi & 0.98 \\
\hline & Cymbaria dahurica & 0.92 \\
\hline & Dianthus chinensis & 2.03 \\
\hline & Heteropappus altaicus & 0.99 \\
\hline & Iris tenuifolia & 0.63 \\
\hline & Ixeris chinensis & \\
\hline & Melilotoides ruthenica & \\
\hline & Oxytropis microphylla & \\
\hline & Phlomis umbrosa & \\
\hline & Plantago asiatica & \\
\hline & Potentilla acaulis & 7.84 \\
\hline & Potentilla anserina & \\
\hline & Potentilla bifurca & 0.70 \\
\hline & Potentilla multifida & \\
\hline & Potentilla tanacetifolia & 1.95 \\
\hline & Saposhnikovia divaricata & \\
\hline & Scorzonera austriaca & \\
\hline & Sibbaldia adpressa & \\
\hline & Stellera chamaejasme & \\
\hline & Thalictrum petaloideum & 0.87 \\
\hline \multirow{2}{*}{$\begin{array}{l}\text { Shrubs and } \\
\text { semi-shrubs (SS) }\end{array}$} & Artemisia frigida & 22.15 \\
\hline & Lespedeza davurica & \\
\hline
\end{tabular}

\subsection{Species richness of different functional groups}

Perennial rhizome grasses (PR) comprised only one species (Leymus chinensis) in our experiment, so there were no changes in species richness of PR. Species richness of perennial bunchgrasses (PB) and annuals (AS) did not show any changes among treatments from 2005 to 2010, ranging from 3 to 4 and 1 to 3 , respectively (Fig. 2). PF showed the highest species richness, ranging from 2 to 10 . However, the effects of year and $\mathrm{N}$ treatment interactions were not significant. In general, species richness of PF declined with increasing $\mathrm{N}$ addition rate. Species richness of PF was not influenced by $\mathrm{N}$ addition treatment in the first year but decreased significantly under the $\mathrm{N}$ addition rate of $48 \mathrm{~g} \mathrm{~N} /\left(\mathrm{m}^{2} \cdot \mathrm{a}\right)$ in the second year. In the following years (from 2008 to 2010) when the $\mathrm{N}$ addition rate was higher than $12 \mathrm{~g} \mathrm{~N} /\left(\mathrm{m}^{2} \cdot \mathrm{a}\right)$ the species richness of $\mathrm{PF}$ declined significantly with increasing $\mathrm{N}$ addition rate (Fig. 2). Species richness of shrubs and semishrubs (SS) (ranging from 1 to 2) did not change significantly with year (Fig. 2).

\subsection{Aboveground biomass of different functional groups}

Increased $\mathrm{N}$ addition significantly stimulated the growth of $\mathrm{PB}$, which had the highest aboveground biomass within our experimental quadrats. In the first year, aboveground biomass of PB ranged from 30 to $90 \mathrm{~g} / \mathrm{m}^{2}$, and growth continued in subsequent years. The highest aboveground biomass of PB was $317 \mathrm{~g} / \mathrm{m}^{2}$ which occurred in the $24 \mathrm{~g} \mathrm{~N} /\left(\mathrm{m}^{2} \cdot \mathrm{a}\right)$ treatment in 2010 . The aboveground biomass of $48 \mathrm{~g} \mathrm{~N} /\left(\mathrm{m}^{2} \cdot \mathrm{a}\right)$ treatment was lower than that of $24 \mathrm{~g} \mathrm{~N} /\left(\mathrm{m}^{2} \cdot \mathrm{a}\right)$ treatment during 2009 and 2010 on account of the cessation of application of $48 \mathrm{~g} \mathrm{~N} /\left(\mathrm{m}^{2} \cdot \mathrm{a}\right)$ during these two years (Fig. 3). Biomass of PF showed a negative relationship with $\mathrm{N}$ addition rate. Compared to the control, biomass of PF declined significantly by $81 \%$ in the highest treatment after merely two years of $\mathrm{N}$ addition. The rate of decline in PF biomass amounted to $49 \%$ at $12 \mathrm{~g} \mathrm{~N} /\left(\mathrm{m}^{2} \cdot \mathrm{a}\right)$ in 2008 and $29 \%$ at $3 \mathrm{~g} \mathrm{~N} /\left(\mathrm{m}^{2} \cdot \mathrm{a}\right)$ in 2009 (Fig. 3). Biomass of PR did not show any response to the interaction between $\mathrm{N}$ addition treatment and year, with lowest and highest aboveground biomass values of $0.21 \mathrm{~g} / \mathrm{m}^{2}$ and $4.09 \mathrm{~g} / \mathrm{m}^{2}$, respectively (Fig. 3). The 
biomass of AS was no more than $8 \mathrm{~g} / \mathrm{m}^{2}$ after 6 years of treatment and had no significant time effect (Fig. 3). There was no significant effect of $\mathrm{N}$ addition on the biomass of SS, which declined with increasing $\mathrm{N}$ addition rate, except in the first year when it showed an increasing trend. During 2006, 2008 and 2009, the biomass of SS started to decline significantly under the addition rates of 48,24 and $12 \mathrm{~g} /\left(\mathrm{m}^{2} \cdot \mathrm{a}\right)$, respectively. However, in 2010 there were no significant differences among treatments (Fig. 3).

\subsection{Height of different functional groups}

Increased $\mathrm{N}$ addition rate significantly increased the height of $\mathrm{PB}$, which ranged from 21 to $55 \mathrm{~cm}$. Despite there were no differences between treatments in the first year, the height of PB sharply increased in 2006, when it peaked during the 6 years of experiments. The $48 \mathrm{~g} \mathrm{~N} /\left(\mathrm{m}^{2} \cdot \mathrm{a}\right)$ treatment had the largest PB height within each year, including 2009 and 2010 when $\mathrm{N}$ addition was terminated (Fig. 4). The height of PF varied from 9 to $20 \mathrm{~cm}$ and was lower than that of PB. In general, the height of $\mathrm{PB}$ increased with $\mathrm{N}$ addition rate. The effect of $\mathrm{N}$ addition on $\mathrm{PF}$ height was slight from 2005 to 2008. During 2009 and 2010, the height of PB in the $48 \mathrm{~g} \mathrm{~N} /\left(\mathrm{m}^{2} \cdot \mathrm{a}\right)$ terminated treatment increased significantly but there were no differences between the other treatments (Fig. 4). SS height was lower than PB but higher than PF. There was no consistent trend in the variation of SS height which ranged from 6 to $33 \mathrm{~cm}$. SS height was relatively lower in 2009 and 2010 than in earlier years (Fig. 4).

\section{Discussion}

Community aboveground biomass increased at every $\mathrm{N}$ addition rate throughout the study years, although

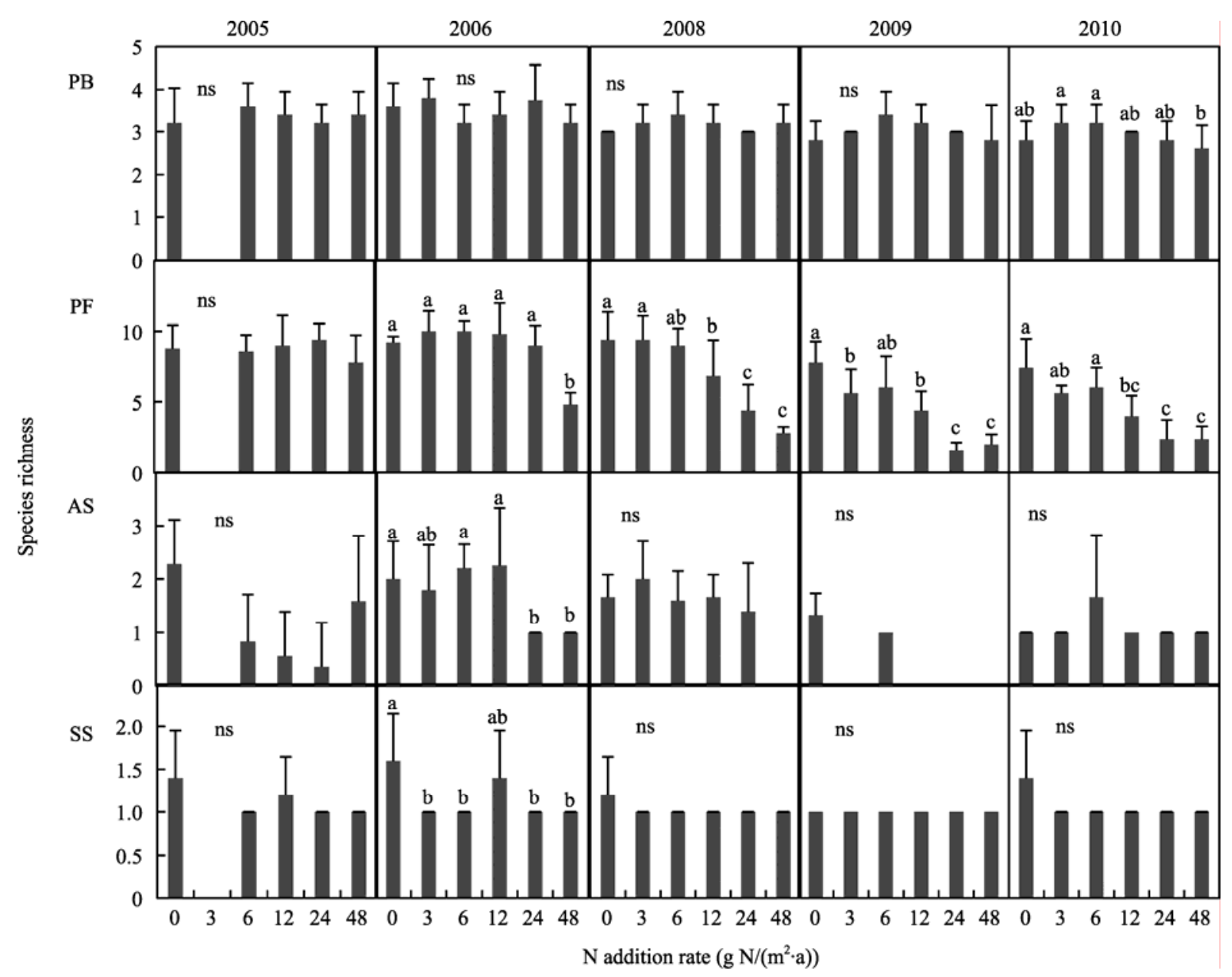

Fig. 2 Effects of increased $N$ addition on species richness of plant functional groups from 2005 to 2010. PB, perennial bunchgrasses; $\mathrm{PF}$, perennial forbs; AS, annuals; SS, shrubs and semi-shrubs. 


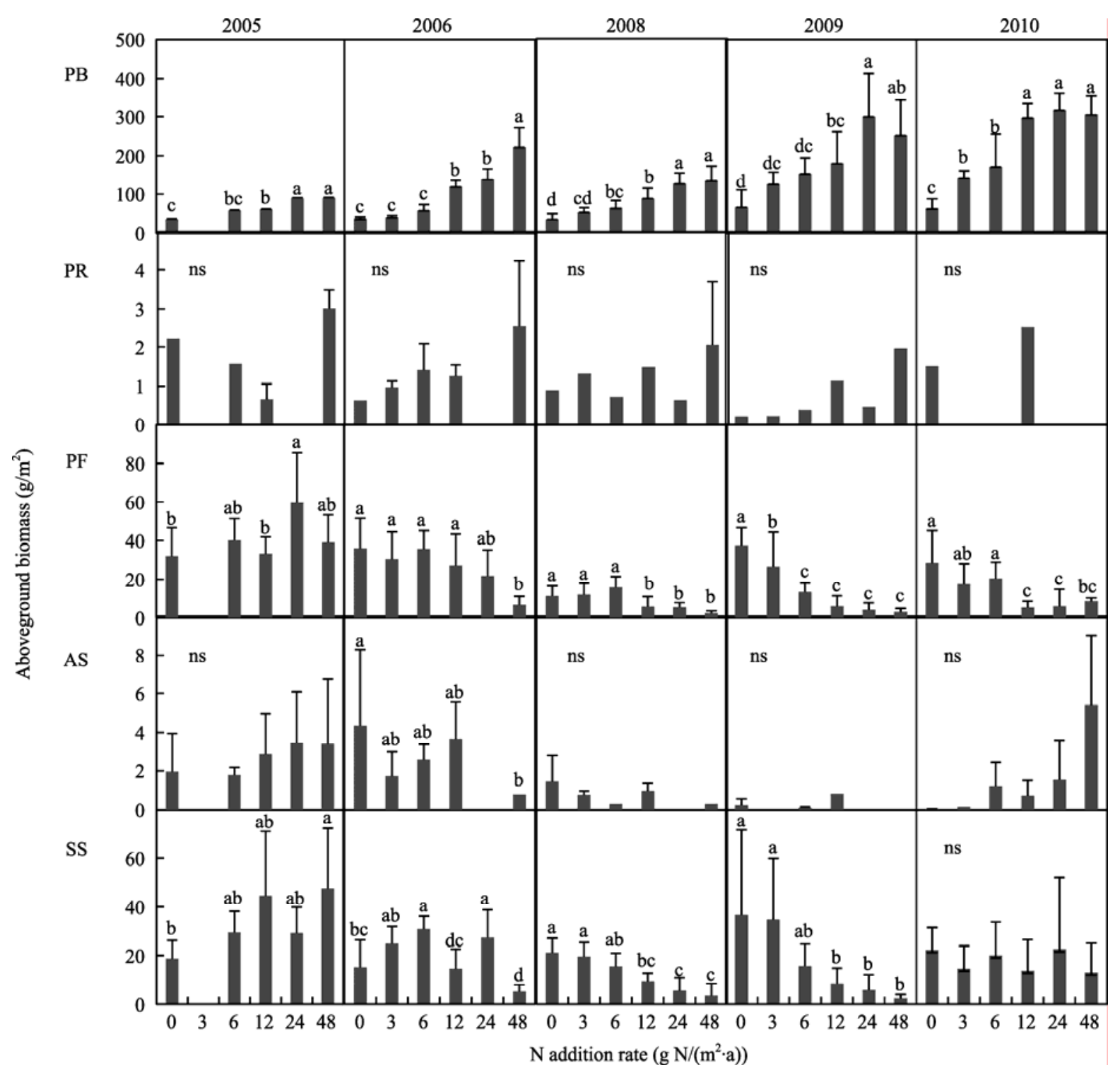

Fig. 3 Effects of increased $\mathrm{N}$ addition on aboveground biomass of plant functional groups from 2005 to 2010. PR, perennial rhizome grasses. See Fig. 2 for the other functional group abbreviations.

there were some differences between individual functional groups. After a 5-year consecutive $\mathrm{N}$ adding, there was no further significant increase of biomass for $24 \mathrm{~g} \mathrm{~N} /\left(\mathrm{m}^{2} \cdot \mathrm{a}\right)$ treatment compared to $12 \mathrm{~g} \mathrm{~N} /\left(\mathrm{m}^{2} \cdot \mathrm{a}\right)$. Besides, the cessation of $\mathrm{N}$ addition in $48 \mathrm{~g} \mathrm{~N} /\left(\mathrm{m}^{2} \cdot \mathrm{a}\right)$ in 2009 and 2010 did not reduce the biomass which was higher than that in lower $\mathrm{N}$ addition rate. These patterns suggest that the aboveground biomass of the study site (as a semi-natural species-rich grassland) was generally limited by $\mathrm{N}$ while it was saturated at $12 \mathrm{~g} \mathrm{~N} /\left(\mathrm{m}^{2} \cdot \mathrm{a}\right)$ after 5 years of $\mathrm{N}$ addition, with corresponding soil $\mathrm{N}$ content in $0-20 \mathrm{~cm}$ depth to be 113 $\mathrm{kg} / \mathrm{hm}^{2}$ according to Song et al. (2011). This N satura- tion threshold agreed well with the value $(10.5 \mathrm{~g}$ $\left.\mathrm{N} /\left(\mathrm{m}^{2} \cdot \mathrm{a}\right)\right)$ from Bai et al. (2010). It should be noted that the $\mathrm{N}$ accumulated in soil could lead to $\mathrm{N}$ eutrophication (Stevens et al., 2006). Eutrophication can cause changes in the rates of soil microbial processes (Aber et al., 2003), reduce soil pH, increase soil nutrient availability, and shift nutrient balance (Roem and Berendse, 2000). Under N saturated condition, the limitation factor may shift from $\mathrm{N}$ to water, phosphorous, or light (Xia and Wan, 2008).

In this study, both $\mathrm{PB}$ and $\mathrm{PF}$ were the dominant species, while PR and AS accounted for only a small proportion of the biomass. The biomass of PB was 


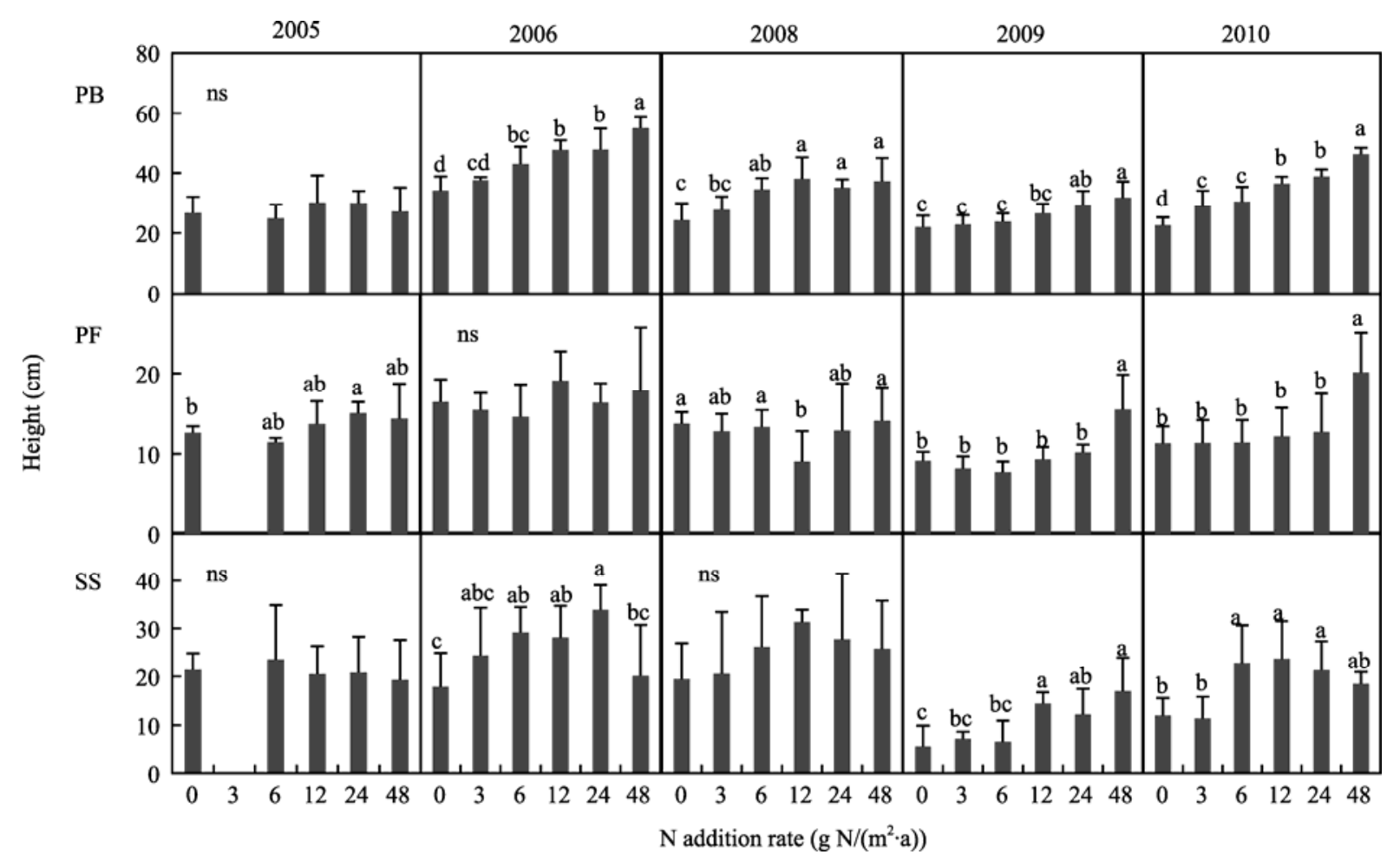

Fig. 4 Effects of increased N addition on the height of plant functional groups from 2005 to 2010 . See Fig.2 for functional group abbreviations.

stimulated significantly by $\mathrm{N}$ addition but the species richness of $\mathrm{PB}$ showed no significant change with $\mathrm{N}$ addition. Both biomass and species richness of $\mathrm{PF}$ were significantly reduced by higher $\mathrm{N}$ addition rates, with only a weak decline in SS, PR and AS found under $\mathrm{N}$ addition. $\mathrm{PF}$ increased in our plots as the years advanced. Our results clearly show that species richness in Inner Mongolia declined strongly with increasing $\mathrm{N}$ addition rate, which is consistent with previous studies. For example, the studies in tundra habitats found that increased $\mathrm{N}$ availability has increased the cover of vascular plants and decreased the cover of bryophytes and lichens (Nilsson et al., 2002; Soudzilovskaia et al., 2005). The same trend was found in alpine and subalpine scrub habitats (Britton and Fisher, 2007). However, the changes in functional groups were different from those observed by Bai et al. (2010). This difference was kept particularly pronounced in PF which is the main functional group that declined significantly in species richness, while changes in other functional groups were slight in our plots, in contrast to the sudden increase in invasion by species of AS accompanied by a decline in species richness according to Bai et al. (2010). Our study area was enclosed to prevent grazing from 2001 onwards and the grassland management may have had some influence on the decline in species richness, but the effects may have been small and much lower than the effects of cumulative N deposition (Dupre et al., 2010). The largest difference exists between two dominant species, Stipa krylovii in our plots and Leymus chinensis in the plots from the study by Bai et al. (2010), which again highlights the site-specific dynamics.

Also in Duolun grassland station, Song et al. (2011) found increased accumulation of soil mineral $\mathrm{N}$, as an important $\mathrm{N}$ resource for plant growth, may favor species with higher $\mathrm{N}$ use efficiency. According to our results, with the increase of soil $\mathrm{N}$ availability, $\mathrm{PB}$ may grow faster than $\mathrm{PF}$, leading to a relatively higher productivity and greater height. As a result, $\mathrm{PB}$, as the dominant functional group in this temperate steppe, suppresses the growth of other groups through competitions for light, nutrient resources or water (Hautier et al., 2009).

\section{Conclusions}

Our study provides further evidence that the semi-arid temperate grassland in China was $\mathrm{N}$ limited and species richness is sensitive to increased $\mathrm{N}$ addition/deposition. And the responses are site-specific and species-specific. The change in species composi- 
tion under $\mathrm{N}$ enrichment was mainly caused by the decreased subdominant species diversity of PF. PB as the dominant group significantly increased the aboveground biomass and height under $\mathrm{N}$ addition regardless of species diversity. Our results showed that $\mathrm{N}$ enrichment would influence community structure and composition at functional level due to different species traits.

\section{References}

Aber J D, Goodale C L, Ollinger S V, et al. 2003. Is nitrogen deposition altering the nitrogen status of northeastern forests? Bioscience, 53(4): 375-389.

Bai Y, Wu J, Clark C M, et al. 2010. Tradeoffs and thresholds in the effects of nitrogen addition on biodiversity and ecosystem functioning: evidence from Inner Mongolia grasslands. Global Change Biology, 16(1): 358-372.

Bobbink R, Ashmore M, Braun S, et al. 2003. Empirical nitrogen critical loads for natural and semi-natural ecosystems: 2002 update. In: Achermann B, Bobbink R. Empirical Critical Loads for Nitrogen. Berne: Swiss Agency for Environment, Forest and Landscape SAEFL, 43-170.

Bobbink R. 2004. Plant species richness and the exceedance of empirical nitrogen critical loads: an inventory. Bilthoven, Utrecht University/RIVM. Report Landscape Ecology.

Bobbink R, Hicks K, Galloway J, et al. 2010. Global assessment of nitrogen deposition effects on terrestrial plant diversity: a synthesis. Ecological Applications, 20(1): 30-59.

Britton A J, Fisher J M. 2007. Interactive effects of nitrogen deposition, fire and grazing on diversity and composition of low-alpine prostrate Calluna vulgaris heathland. Journal of Applied Ecology, 44(1): 125-135.

Chen Q, Hooper D U, Lin S. 2011. Shifts in species composition constrain restoration of overgrazed grassland using nitrogen fertilization in Inner Mongolian steppe, China. PLoS ONE, 6(3): e16909. doi:10.1371/journal.pone.0016909.

Clark C M, Tilman D. 2008. Loss of plant species after chronic low-level nitrogen deposition to prairie grasslands. Nature, 451: 712-715.

Dupre C, Stevens C J, Ranke T, et al. 2010. Changes in species richness and composition in European acidic grasslands over the past 70 years: the contribution of cumulative atmospheric nitrogen deposition. Global Change Biology, 16(1): 344-357.

Emmett B A. 2007. Nitrogen saturation of terrestrial ecosystems: some recent findings and their implications for our conceptual framework. Water, Air and Soil Pollution: Focus, 7(1-3): 99-109.

Hautier Y, Niklaus P A, Hector A. 2009. Competition for light causes plant biodiversity loss after eutrophication. Science, 324(5927): 636-638.

He C E, Liu X J, Christie P, et al. 2010. Estimating total nitrogen deposition in agroecosys-tems in northern China during the wheat cropping season. Journal of Arid Land, 2(1): 2-8.

Jones D L, Kielland K. 2002. Soil amino acid turnover dominates the nitrogen flux in permafrost-dominated taiga forest soils. Soil Biology and Biochemistry, 34(2): 209-219.

Liu X J, Duan L, Mo J M, et al. 2011. Nitrogen deposition and its

\section{Acknowledgments}

This work was supported by the One Hundred Person Project of Chinese Academy of Sciences, the National Natural Science Foundation of China $(40771188,41071151)$, the Innovative Group Grants from NSFC (30821003) and the Sino-German project (DFG Research Training Group, GK1070).

ecologyical impact in China: an overview. Environmental Pollution, 159(10): 2251-2264.

Lu M, Yang Y H, Luo Y Q, et al. 2011. Responses of ecosystem nitrogen cycle to nitrogen addition: a meta-analysis. New Phytologist, 189(4): 1040-1050.

Matson P, Lohse K A, Hall S J. 2002. The globalization of nitrogen deposition: consequences for terrestrial ecosystems. Ambio, 31(2): 113-119.

NADP (National Atmospheric Deposition Program), 2000. National Atmospheric Deposition Program Annual Data Summary: Precipitation Chemistry in the United States. NADP Program Office, Illinois State Water Survey, University of Illinois, Champaign.

Nilsson M C, Wardle D A, Zackrisson O, et al. 2002. Effects of alleviation of ecological stresses on an alpine tundra community over an eight-year period. Oikos, 97(1): 3-17.

Niu S L, Wu M Y, Han Y, et al. 2010. Nitrogen effects on net ecosystem carbon exchange in a temperate steppe. Global Change Biology, 16(1): 144-155.

Roem W J, Berendse F. 2000. Soil acidity and nutrient supply ratio as possible factors determining changes in plant species diversity in grassland and heathland communities. Biological Conservation, 92(2): 151-161.

Shen J L, Tang A H, Liu X J, et al. 2009. High concentrations and dry deposition of reactive nitrogen species at two sites in the North China Plain. Environmental Pollution, 157(11): 3106-3113.

Song L, Bao X M, Liu X J, et al. 2011. Nitrogen enrichment enhances the dominance of grasses over forbs in a temperate steppe ecosystem. Biogeosciences, 8: 2341-2350.

Soudzilovskaia N A, Onipchenko V G, Cornelissen J H C, et al. 2005. Biomass production, $\mathrm{N}: \mathrm{P}$ ratio and nutrient limitation in a Caucasian alpine tundra plant community. Journal of Vegetation Science, 16(4): 399-406.

Stevens C J, Dise N B, Mountford J O, et al. 2004. Impact of nitrogen deposition on the species richness of grasslands. Science, 303(5665): 1876-1879.

Stevens C J, Dise N B, Gowing D J G, et al. 2006. Loss of forb diversity in relation to nitrogen deposition in the UK: regional trends and potential controls. Global Change Biology, 12(10): 1823-1833.

Xia J Y, Wan S Q. 2008. Global response patterns of terrestrial plant species to nitrogen addition. New Phytologist, 179(2): 428-439.

Zhang Y, Liu X J, Fangmeier A, et al. 2008. Nitrogen inputs and isotopes in precipitation in the North China Plain. Atmospheric Environment, 42(7): 1436-1448. 